\title{
Analisis Fungsi Jasa Bio-Ekologis Hutan Kota Kawasan Industri
}

\author{
Akhmad Syihabuddin a*, Budi Darmadi a, Tarsoen Waryono ${ }^{\text {a }}$ \\ a Program Studi Ilmu Lingkungan Universitas Indonesia. Jl. Salemba Raya 4, Jakarta Pusat, Jakarta, Indonesia \\ *Email: akhmad.syihabuddin@ui.ac.id \\ Diterima (received) 13 Desember 2019; disetujui (accepted) 1 Februari 2020; tersedia secara online (available online) 1 Februari 2020
}

\begin{abstract}
The construction of green areas in the form of urban forests around the industrial area on the belief Pulogadung role bio-ecological service, functions of various types of plant communities is considered capable of improving the environmental quality of industrial estates. The purposes of study: (1) analyze the dynamics of the urban forest tree growth; (2) analyze the micro-climatic conditions; (3) to analyze the carbon stored amount; (4) analyze the knowledge and attitudes; and (5) urban forest management analyze the industrial area. The study was conducted in Urban forest Industrial Estate Pulogadung, East Jakarta. Samples of vegetation consist of three single swath, while human sample consisted of 40 respondents and two informants. The structure and composition of vegetation that dominates in the Urban forest Industrial Estate Pulogadung Samanea saman for phase trees with IVI 67.68\%; Swietenia mahagoni for phase pole with IVI $241.846 \%$; Leucaena leucocephala for phase stake with IVI $126.13 \%$. The growth dynamics of urban forest tree unnatural. Micro-climatic conditions in the category uncomfortable are 29.75 , whereas the condition ideally convenient in the range $25.0-27.0^{\circ} \mathrm{C}$. The amount of carbon stocks in urban forest Industrial Estate Pulogadung of 77.27 tons/ha, while the average carbon density per hectare is 283.3 tons/ha. People's knowledge of the existence of the benefits of urban forests Industrial Estate Pulogadung as a producer of oxygen is greater $(97.5 \%)$ of the thermostat $(90 \%)$, and infiltration of rainwater $(82.5 \%)$, while public attitudes as much as $83.75 \%$ agree to participate in managing the urban forest Industrial Estate Pulogadung.
\end{abstract}

Keywords: architectural profile; microclimate; carbon uptake; public perception; urban forests, industrial areas

\begin{abstract}
Abstrak
Pembangunan kawasan hijau berupa hutan kota di sekitar kawasan industri Pulogadung diyakini memiliki peran jasa bioekologi, fungsi berbagai jenis tumbuhan masyarakat dinilai mampu meningkatkan kualitas lingkungan kawasan industri. Tujuan kajian: (1) menganalisis dinamika pertumbuhan pohon di hutan kota; (2) menganalisis kondisi iklim mikro; (3) menganalisis jumlah karbon yang disimpan; (4) menganalisis pengetahuan dan sikap; dan (5) pengelolaan hutan kota menganalisis kawasan industri. Penelitian dilakukan di Kawasan Industri Hutan Kota Pulogadung, Jakarta Timur. Sampel vegetasi terdiri dari tiga petak tunggal, sedangkan sampel manusia terdiri dari 40 responden dan dua informan. Struktur dan komposisi vegetasi yang mendominasi di Hutan Kota Kawasan Industri Pulogadung Samanea saman untuk pohon fase dengan INP 67,68\%; Swietenia mahagoni untuk tiang fase dengan INP 241,85\%; Leucaena leucocephala untuk saham fase dengan INP $126,13 \%$. Dinamika pertumbuhan pohon hutan kota tidak wajar. Kondisi iklim mikro dalam kategori tidak nyaman adalah 29,75 , sedangkan kondisi idealnya nyaman pada kisaran $25,0-27,0^{\circ} \mathrm{C}$. Besarnya stok karbon di Hutan Kota Kawasan Industri Pulogadung sebesar 77,27 ton/ha, sedangkan kerapatan karbon rata-rata per hektar adalah 283,30 ton/ha. Pengetahuan masyarakat tentang adanya manfaat hutan kota Kawasan Industri Pulogadung sebagai penghasil oksigen lebih besar $(97,5 \%)$ dari thermostat $(90,00 \%)$, dan infiltrasi air hujan $(82,50 \%)$, sedangkan sikap masyarakat sebanyak $83,75 \%$ setuju untuk ikut serta mengelola Hutan Kota Kawasan Industri Pulogadung.
\end{abstract}

doi: https://doi.org/10.24843/blje.2020.v20.i01.p01

(C) 2019 by the authors; Content from this work may be used under the terms of the Creative Commons Attribution 3.0 licence. Any further distribution of this work must maintain attribution to the author(s) and the title of the work, journal citation and DOI. Published under licence by Udayana University, Indonesia. 
Kata Kunci: profil arsitektur; iklim mikro; serapan karbon; persepsi publik; hutan kota; kawasan industri

\section{Pendahuluan}

Menurunnya daya dukung lingkungan sebagai akibat dari pencemaran udara, umumnya bersumber dari kendaraan bermotor. Selama jangka waktu lima tahun terakhir $(2010-2014)$ antara lain meningkatnya pencemaran $\mathrm{CO}_{2}$ dari rata-rata $183,2 \mathrm{mg} / \mathrm{m}^{2}$ menjadi $302,4 \mathrm{mg} / \mathrm{m}^{2}$. Kadar debu dari ratarata $187,9 \mathrm{mg} / \mathrm{m}^{2}$ meningkat menjadi $443,0 \mathrm{mg} / \mathrm{m}^{2}$. Kadar timbal $(\mathrm{Pb})$ meningkat dari rata-rata 262,3 $\mathrm{mg} / \mathrm{m}^{2}$ menjadi $407,3 \mathrm{mg} / \mathrm{m}^{2}$, demikian halnya dengan tingkat kebisingan dari rata - rata $33,4 \mathrm{~dB}$ meningkat menjadi 43,6 dB (BPLHD, 2015). Keberadaan tersebut selama jangka waktu 5 tahun terakhir, suhu udara di wilayah Jakarta telah mengalami peningkatan dari rata-rata suhu udara $30,7^{\circ} \mathrm{C}$ meningkat menjadi $31,2^{\circ} \mathrm{C}$, sedangkan kontribusi kegiatan transportasi sebagai sumber polusi dalam bentuk emisi gas karbon dioksida $\left(\mathrm{CO}_{2}\right)$ mencapai 206.797.291,46 ton $\mathrm{CO}_{2}$ per tahun (BPLHD, 2015). Keadaan tersebut berdampak negatif terhadap kualitas udara di wilayah DKI Jakarta.

Salah satu fenomena permasalahan di lingkungan perkotaan adalah berkurangnya rasa kenyamanan sebagai akibat meningkatnya suhu udara, banyaknya jalan beraspal dan betonan, dan bangunan bertingkat. Menurut Waryono (2010) bahwa kualitas lingkungan hidup di wilayah perkotaan, sangat ditentukan oleh keseimbangan alam seperti dirumuskan dalam proses fotosintesa. Pada proses fotosintesis melalui reaksi $6 \mathrm{CO}_{2}+6 \mathrm{H}_{2} \mathrm{O}+$ katalis (sinar matahari + klorofil) akan menghasilkan $6 \mathrm{C}_{6} \mathrm{H}_{12} \mathrm{O}_{6}+6 \mathrm{O}_{2}$. Pada proses tersebut, oksigen $\left(\mathrm{O}_{2}\right)$ diilustrasikan sebagai kenyamanan lingkungan hidup, sedangkan glukosa $\left(\mathrm{C}_{6} \mathrm{H}_{12} \mathrm{O}_{6}\right)$ diilustrasikan sebagai potensi kawasan hijau. Berbeda halnya dengan karbon dioksida $\left(\mathrm{CO}_{2}\right)$ merupakan sumber polutan yang dimanfaatkan oleh hijau daun atas bantuan sinar matahari. Selain menghasilkan oksigen, hijau daun secara komunitas hijauan perkotaan juga memiliki peranan fungsi jasa bio-eko-hidrologis.

Hutan kota (urban forest), pada hakekatnya adalah komunitas tumbuhan alami (natural vegetation) yang dipertahankan dan atau merupakan komunitas tumbuhan yang dibangun dan dibina di wilayah perkotaan, hingga membentuk tegakan vegetasi berkayu, beserta semak dan tumbuhan bawahnya yang membentuk satuan ekologik terkecil, seperti pembangunan hutan kota yang dikembangkan di kawasan industri Pulogadung. Hutan kota kawasan industri PT. Jakarta Industrial Estate Pulogadung (JIEP) adalah salah satu hamparan kawasan hijau binaan dalam bentuk hutan kota kawasan industri. Hutan Kota tersebut telah dikukuhkan melalui Surat Keputusan Gubernur Nomor 870 tahun 2004, dengan luas 8,9 ha. Dalam keputusan tersebut bahwa tipe hutan kota kawasan industri diperankan sebagai penyangga kawasan industri yang memiliki peranan fungsi jasa bio-ekologis.

Dibangunnya kawasan hijau dalam bentuk hutan kota di sekitar kawasan industri Pulogadung atas dasar keyakinan peranan fungsi jasa bioekologis komunitas berbagai jenis tumbuhan yang dinilai mampu dalam memodifikasi iklim mikro, mengurangi kecepatan angin, meningkatkan radiasi gelombang panjang, menahan tetesan air hujan, pendinginan udara melalui evapotranspirasi dan meningkatkan kelembaban udara.

Atas dasar itulah penelitian peranan fungsi jasa bio-ekologis kawasan hijau hutan kota di kawasan industri Pulogadung (PT. JIEP) menjadi penting untuk dilakukan. Tujuan dari penelitian ini adalah mengidentifikasi dinamika pertumbuhan pohon, kondisi iklim mikro, kemampuan karbon tersimpan, dan persepsi masyarakat terhadap keberadaan hutan kota kawasan industri Pulogadung.

\section{Metode Penelitian}

Penelitian dilakukan di Hutan Kota kawasan industri Pulogadung antara bulan September 2016 hingga Desember 2016. Pendekatan penelitian yang digunakan adalah pendekatan kuantitatif yaitu dengan metode observasi lapangan dan teknik pengambilan data menggunakan kuesioner tertutup dan wawancara. Populasi dalam penelitian ini adalah semua area vegetasi dalam Hutan Kota kawasan industri Pulogadung selama bulan Septermber 2016 hingga Desember 2016, sampel diambil dengan melakukan analisis vegetasi dengan cara membuat tiga petak tunggal. Intensitas sampling yang diambil mengacu 
pada Peraturan Menteri Kehutanan Nomor P.67/MenhutII/2006 Tentang Kriteria dan Standar Inventarisasi Hutan yaitu minimal

\section{Hasil dan Pembahasan}

\subsection{Dinamika Pertumbuhan Pohon}

Berdasarkan hasil pengukuran pada tiga petak tunggal diperoleh bahwa nilai kerapatan tegakan tingkat pertumbuhan pohon yaitu 225 individu/ha, tingkat pertumbuhan tiang yaitu 234 individu/ha, tingkat pertumbuhan pancang yaitu 2.934 individu/ha, dan tingkat pertumbuhan semai yaitu 10.834 individu/ha. Terlihat bahwa semakin rendah tingkat pertumbuhan, maka semakin tinggi kerapatan tegakannya. Apabila dibandingkan dengan kerapatan tegakan tiap tingkat pertumbuhan vegetasi, dapat diketahui bahwa tingkat semai dan pancang memiliki kerapatan tegakan tinggi dibandingkan tingkat pertumbuhan tiang dan pohon yang memiliki kerapatan tegakan lebih rendah. Oleh karena itu dapat dikatakan status regenerasi tegakan hutan kota dapat dikatakan baik, sesuai dengan pendapat Utami et al., (2014).

Berdasarkan hasil perhitungan Indeks Shannon memperlihatkan bahwa pada tingkat semai sebesar 0,62 , pada tingkat pancang yaitu sebesar 1,37 , pada tingkat tiang yaitu sebesar 0,67 , dan pohon yaitu sebesar 1,94. Berdasarkan hasil perhitungan tersebut, maka keanekaragaman pada tingkat pohon dan pancang termasuk kedalam keanekaragaman sedang, sedangkan pada tingkat pertumbuhan tiang dan semai masuk pada keanekaragaman rendah. Hal ini dikarenakan Hutan Kota kawasan industri Pulogadung bukanlah hutan alami melainkan hutan buatan. Artinya semua vegetasi yang di tanaman disesuaikan dengan tujuan dari pembangunannya. Lebih jauhnya jumlah jenis vegetasi yang tumbuh di hutan buatan akan tidak sebanyak jenis vegetasi yang tumbuh di hutan alami.

Metode profil vegetasi menunjukkan kriteria pohon masa datang, masa kini, dan masa lampau. Berdasarkan hasil pengamatan pada tiga petak tunggal di hutan kota kawasan industri Pulogadung, vegetasi hutan kota didominasi oleh pohon masa kini (Tabel 1). Kerapatan vegetasi pohon di hutan kota kawasan industri Pulogadung sebesar 225 individu/ha. Jenis vegetasi yang ditemukan fase pohon sampai tumbuhan penutup tanah 8 jenis.

Tabel 1. Kerapatan pohon pada hutan kota kawasan industri Pulogadung.

\begin{tabular}{ccccc}
\hline Nama Daerah & Nama Ilmiah & PMK & PMD & Kerapatan (Ind/ha) \\
\hline Trembesi & Samanea saman & 33 & 0 & 33 \\
Angsana & Pterocarpus indicus & 33 & 0 & 33 \\
Akasia & Acacia crassicarpa & 17 & 0 & 17 \\
Petai cina & Leucaena leucocephala & 33 & 0 & 33 \\
Beringin & Ficus benjamina & 42 & 0 & 42 \\
Mahoni & Swietenia mahagoni & 33 & 0 & 33 \\
Ketapang & Terminalia catappa & 25 & 0 & 25 \\
Kordia & Cordia dichotoma & 8 & 0 & 8 \\
\hline
\end{tabular}

\subsection{Judul sub-bab}

Biomassa memiliki kaitan dengan cadangan karbon, yaitu dengan mengukur jumlah cadangan karbon pada suatu lahan dapat menggambarkan banyaknya karbon di atmosfer yang dapat diserap oleh pohon. 
Tabel 2. Kemampuan karbon tersimpan pohon hutan kota kawasan industri.

\begin{tabular}{ccc}
\hline Nama Daerah & Nama Ilmiah & $\begin{array}{c}\text { Besaran Karbon Tersimpan } \\
\text { (tonC/ha) }\end{array}$ \\
\hline Angsana & Pterocarpus indicus & 6,50 \\
akasia & Acacia crassicarpa & 0,64 \\
beringin & Ficus benjamina & 27,12 \\
kordia & Cordia dichotoma & 0,06 \\
ketapang & Terminalia catappa & 8,44 \\
mahoni & Swietenia mahagoni & 16,65 \\
Petai cina & Leucaena leucocephala & 0,44 \\
Trembesi & Samanea saman & 19,43 \\
\hline
\end{tabular}

Berdasarkan hasil analisis yang dilakukan (Tabel 2), kandungan karbon rata-rata pohon hutan kota kawasan industri Pulogadung adalah sebesar 77,27 ton/ha, sedangkan hasil perhitungan rata-rata potensi karbon per hektar adalah 283,3 ton/ha. Kandungan karbon pada tanaman menunjukkan berapa besar tanaman tersebut dapat mengikat karbondioksida di udara (Heriyanto dan Endro, 2007).

Berdasarkan Tabel 2, Pohon Beringin (Ficus Benjamina) memiliki besaran karbon terbesar yakni 27,12 ton/ha. Besaran rata-rata diameter batang dan jumlah individu yang ada di hutan kota kawasan industri Pulogadung berpengaruh pada nilai karbon tersimpan pada masing-masing jenis pohon. Hal tersebut diperkuat oleh Heriyanto dan Endro (2007) bahwa fotosintesis digunakan tumbuhan untuk melakukan perkembangan kearah horizontal dan vertikal, sehingga semakin besarnya diameter disebabkan oleh penyimpanan biomassa hasil konversi $\mathrm{CO}_{2}$ yang semakin bertambah besar seiring dengan semakin banyaknya $\mathrm{CO}_{2}$ yang diserap oleh pohon.

\subsection{Kondisi Iklim Mikro}

Berdasarkan pengukuran iklim mikro pada pagi hari dapat diketahui bahwa kondisi Indeks Kenyamanan (IK) pada petak 1 dan petak 3 pada pagi hari berada pada kategori sebagian tidak nyaman, sedangkan kondisi petak 2 IK pada kategori tidak nyaman. Berdasarkan observasi di lapangan, kondisi petak 2 merupakan areal terbuka yang memiliki jenis pohon yang baru ditanam yang diameternya kurang dari $50 \mathrm{~cm}$, sehingga kondisi pada plot tersebut masuk pada kategori tidak nyaman.

Tabel 3. Indeks kenyamanan lingkungan kondisi pagi hari.

\begin{tabular}{ccc}
\hline Plot & Real IK & Ideal IK \\
\hline 1 & 27,05 & $25-26,99$ \\
2 & 29,65 & $25-26,99$ \\
3 & 28,05 & $25-26,99$ \\
\hline
\end{tabular}

Pada pengukuran iklim mikro pada kondisi siang hari didapatkan hasil bahwa semua titik pengamatan memiliki indeks kenyamanan dalam kategori tidak nyaman. Hal tersebut dikarenakan adanya faktor lingkungan yaitu cahaya matahari dan didukung dengan kerapatan tajuk pohonnya yang didominasi kerapatan tajuk rendah dan sedang. 
Tabel 4. Indeks kenyamanan lingkungan kondisi siang hari.

\begin{tabular}{ccc}
\hline Plot & Real IK & Ideal IK \\
\hline 1 & 29,65 & $25-26,99$ \\
2 & 31,95 & $25-26,99$ \\
3 & 30,05 & $25-26,99$ \\
\hline
\end{tabular}

Berdasarkan hasil pengukuran iklim mikro pada waktu sore hari didapatkan bahwa terjadinya perubahan indeks kenyamanan lingkunganan pada semua petak. Pada waktu sore hari semua petak memiliki indeks kenyamanan lingkungan yang masuk ke dalam kategori tidak nyaman.

Tabel 5. Indeks kenyamanan lingkungan kondisi sore hari.

\begin{tabular}{ccc}
\hline Plot & Real IK & Ideal IK \\
\hline 1 & 30,21 & $25-26,99$ \\
2 & 30,18 & $25-26,99$ \\
3 & 29,76 & $25-26,99$ \\
\hline
\end{tabular}

Kondisi hutan kota yang berada diareal padat aktivitas industri menyebabkan kondisi suhu dan kelembaban di hutan kota kawasan industri Pulogadung berada dalam kategori tidak nyaman, selain itu juga renggangnya vegetasi penyusun hutan kota kawasan industri Pulogadung menambah kondisi hutan kota memiliki suhu yang tinggi. Berdasarkan hasil pengukuran suhu dan kelembaban udara di tiga waktu yaitu pagi, siang, dan sore secara keseluruhan didapatkan indeks kenyamanan (IK) lingkungan yaitu 31,11. Artinya kondisi lingkungan Hutan kota kawasan industri Pulogadung masuk kategori tidak nyaman dengan kisaran IK $>29,0$.

\subsection{Persepsi Masyarakat}

Persepsi masyarakat diukur berdasarkan pengetahuan dan sikap masyarakat terhadap keberadaan hutan kota kawasan industri Pulogadung. Berdasarkan hasil kuesioner bahwa mayoritas pengetahuan masyarakat mengenai fungsi ekologis hutan kota kawasan industri Pulogadung adalah positif atau masyarakat mengetahui. Meskipun terdapat adanya perbedaan pada hasil persentase tingkat pengetahuan pada masing-masing komponen pengetahuan. Hasil yang diperoleh bahwa tingkat pengetahuan masyarakat mengenai fungsi hutan kota sebagai penghasil oksigen adalah lebih besar, dari pada pengetahuan mengenai penyerapan karbon, pengatur resapan air hujan, pengatur suhu, dan sebagai habitat burung (Gambar 1).

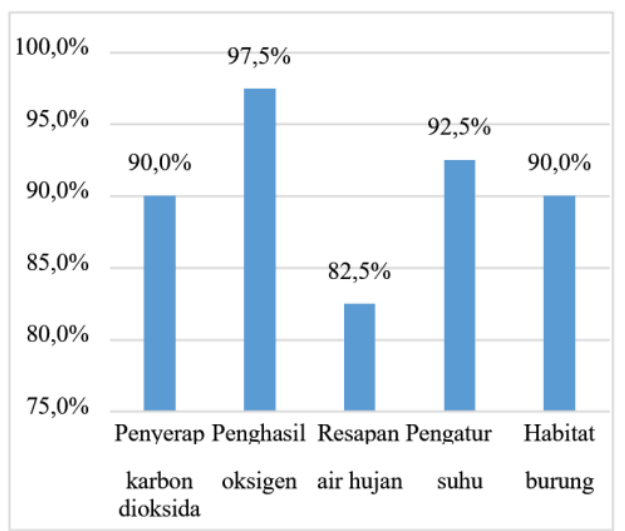

Gambar 1. Pengetahuan masyarakat tentang fungsi jasa ekologis hutan kota kawasan industri Pulogadung. 
Tingkat pengetahuan masyarakat tentang fungsi hutan kota kawasan industri sebagai penyerap karbon dioksida sebanyak 90\%. Hal tersebut dikarenakan informasi mengenai penyerapan karbon dioksida telah banyak dilakukan oleh Pemerintah. Tingkat pengetahuan masyarakat mengenai fungsi keberadaan hutan kota sebagai penyerapan karbon dioksida dapat ditingkatkan melalui pemberian papan edukasi. Hal tersebut bertujuan agar masyarakat ketika sedang mengunjungi hutan kota kawasan industri Pulogadung juga memperoleh pengetahuan tambahan dari keberadaan papan edukasi.

Pengetahuan masyarakat mengenai fungsi jasa ekologis hutan kota kawasan industri Pulogadung sebagai penghasil oksigen sebanyak $97,5 \%$. Tingginya pengetahuan pengunjung terhadap fungsi hutan kota kawasan industri Pulogadung sebagai penghasil oksigen, selain disebabkan oleh banyaknya sumber informasi (faktor pengulangan) diduga disebabkan oleh besarnya intensitas hubungan yang dapat dijalin melalui pendidikan non formal, kegiatan yang dilakukan, dan intensitas kontak dengan lokasi hutan kota kawasan industri Pulogadung (Rivai, 2004).

Pengetahuan masyarakat mengenai fungsi jasa ekologis hutan kota kawasan industri Pulogadung sebagai daerah resapan air hujan didapati hasil terendah yaitu sebesar 82,5\% (Gambar 2). Berbeda halnya dengan pengetahuan masyarakat mengenai fungsi hutan kota kawasan industri Pulogadung sebagai penghasil oksigen yang didapati hasil perolehan terbesar yakni 97,5\%. Hal tersebut dikarenakan masyarakat tidak dapat melihat secara langsung mengenai fungsi penyerapan air hujan pada hutan kota kawasan industri Pulogadung. Rendahnya pengetahuan masyarakat mengenai hal tersebut dikarenakan sesuai dengan kondisi berdasarkan observasi lapangan bahwa kondisi hutan kota kawasan industri Pulogadung yang kurang terawat dan terkesan tidak adanya upaya perawatan yang dilakukan pihak pengelola kawasan industri Pulogadung maupun Pemerintah Provinsi DKI Jakarta.

Masyarakat mengetahui bahwa fungsi hutan kota kawasan industri Pulogadung sebagai pengatur suhu dilingkungannya sebesar $97,5 \%$. Pengetahuan masyarakat mengenai fungsi ekologis Hutan kota sebagai penyedia habitat burung yaitu sebesar $90 \%$. Hal tersebut dikarenakan masyarakat secara langsung dapat menikmati keberadaan dan keindahan dari adanya burung. Pengetahuan masyarakat mengenai fungsi hutan kota kawasan industri Pulogadung sebagai penyedia habitat burung dapat disempurnakan jika terdapat informasi yang terkait dengan jenis burung yang terdapat di hutan kota kawasan industri Pulogadung.

Berdasarkan hasil kuesioner mengenai sikap masyarakat untuk menerima dan ikut berpartisipasi untuk menjaga hutan kota kawasan industri Pulogadung mayoritas menjawab setuju. Mayoritas masyarakat setuju dengan persentase yakni sebesar $83,2 \%$, jika adanya sanksi yang diberlakukan pada seseorang apabila melakukan tindakan penebangan pohon pada areal hutan kota kawasan industri Pulogadung.

Mayoritas masyarakat menyetujui mengenai penambahan pohon di hutan kota kawasan industri Pulogadung yakni sebesar $86,8 \%$. Hal tersebut diperkuat dengan sikap positif masyarakat untuk turut serta berpartisipasi dalam mengikuti program penanaman pohon yakni sebesar $81,2 \%$. Selain itu juga, sebesar 83,8\% masyarakat setuju bahwa pengelolaan hutan kota kawasan industri Pulogadung dilakukan secara bersama-sama. Dalam hal ini masyarakat turut andil dalam menjaga kebersihan lingkungan hutan kota kawasan industri Pulogadung. Sikap positif masyarakat terhadap rencana kegiatan lingkungan merupakan modal yang penting bagi masyarakat bagi perbaikan pengelolaan. Hal tersebut diperkuat oleh Wang et al. (2013) bahwa peran serta masyarakat menjadi hal penting dalam keberlanjutan ruang terbuka hijau. Sementara itu, mayoritas masyarakat setuju dengan persentase yakni sebesar $83,1 \%$, jika adanya sanksi yang diberlakukan pada seseorang apabila melakukan tindakan membuang sampah sembarangan pada areal hutan kota kawasan industri Pulogadung. 


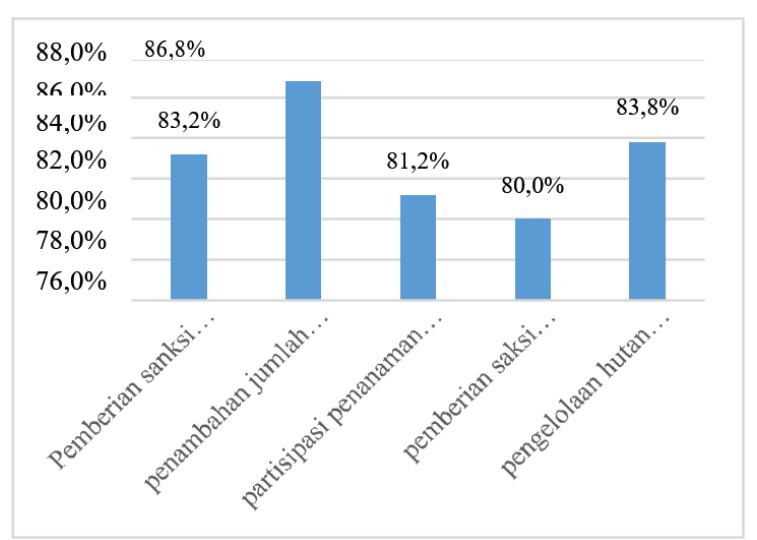

Gambar 2. Sikap masyarakat terhadap keberadaan hutan kota kawasan industri Pulogadung.

\section{Simpulan}

Berdasarkan hasil dan pembahasan, maka dapat ditarikkesimpulan sebagai berikut:

1. Berdasarkan dinamika pertumbuhan pohon vegetasi pada hutan kota kawasan industri Pulogadung, didominasi oleh pohon masa kini sebesar $100 \%$, dengan pohon dominan Trembesi (Samanea saman) dengan INP sebesar 72,98\%.

2. Kondisi iklim mikro di hutan kota kawasan industry Pulogadung berdasarkan elemen suhu dan kelembaban udara menunjukkan bahwa indeks kenyamanan berada pada kategori tidak nyaman.

3. Besaran kemampuan karbon tersimpan pada hutan kota kawasan industri Pulogadung adalah 77,27 ton karbon per hektar, sedangkan rata-rata potensi karbon per hektar adalah 283,3 ton karbon per hektar.

4. Kondisi pengetahuan dan sikap masyarakat mengenai manfaat keberadaan hutan kota kawasan industri Pulogadung, yaitu:

a. Pengetahuan masyarakat mengenai manfaat keberadan hutan kota kawasan industri pulogadung sebagai penghasil oksigen sebear $97,50 \%$; pengatuh suhu udara sebesar 92,50\%; penyerap karbon dioksida sebesar 90,00\%; habitat burung sebesar 90,00\%; dan resapan air hujan sebesar $82,50 \%$.

b. Sikap masyarakat dalam turut serta menjaga keberadan hutan kota kawasan industri Pulogadung adalah sangat setuju.

\section{Daftar Pustaka}

BPLHD. (2015). Laporan Status Lingkungan Hidup Daerah Provinsi Daerah Khusus Ibukota Tahun 2015. Jakarta: BPLH DKI Jakarta.

Heriyanto, N., \& Endro, S. (2007). Komposisi dan Struktur Tegakan, Biomassa, dan Potensi Kandungan Karbon HUtan Magrove di Taman Nasional Alas Purwo. Jurnal Penelitian Hutan dan KOnservasi Alam, 9(1), 23-32.

Rivai, V. (2004). Kepemimpinan dan Perilaku Organisasi. Jakarta: Raja Grafindo.

Utami, S., Anggoro, S., \& Soeprobowati, T. (2014). Regenerasi Tegakan pohon di Hutan Lindung Panjang Kabupaten Jepara Jawa Tengah. Prosiding seminar Nasional Biologi 29 November 2014. Semarang: Universitas Negeri Semarang.

Peraturan Menteri Kehutanan Nomor 67 tahun 2006 Tentang Kriteria dan Standar inventarisasi

Wang, B., Wei, W., Liu, C., \& Niu, X. (2013). Biomass and Carbon Stock in Moso Bamboo Forest in SUbtropical China: Characteristic and Implementations. Journal of Tropical Forest Science, 25(1), 137-148.

Waryono, T. (2010). Pembangunan dan Pengelolaan Hutan KOta. Depok: Universitas Indonesia 